\title{
PENGARUH SIKAP KREATIF TERHADAP \\ PRESTASI BELAJAR MATEMATIKA
}

\author{
Nurul Farida \\ FKIP Universitas Muhammadiyah Metro \\ E-mail : nurulfarida.maniz@yahoo.com
}

\begin{abstract}
The aim of the research was to determine the effect of creative attitude on mathematics achievement. The population was the students in grade VIII junior high school in Central Lampung Regency. The conclusions of the research was students who have high creative attitude have better mathematics learning achievement than students who have middle and low creative attitude.
\end{abstract}

Keyword: Creative attitude, learning mathematics.

\section{PENDAHULUAN}

Matematika merupakan salah satu pelajaran di sekolah yang menuntut peserta didik untuk berpikir kritis dan rasional. Tidak hanya itu, belajar matematika membuat peserta didik berpikir sistematis dalam menyelesaikan permasalahan matematika, yang berdampak pada penyelesaian masalah dalam kehidupan sehari-hari. Namun demikian, pembelajaran yang dilakukan di dalam kelas belum optimal.

Selama ini, pembelajaran matematika yang dilakukan di sekolah masih cenderung monoton. Hal ini terbukti berdasarkan data dari Pusat Penilaian Pendidikan Tahun 2011 bahwa dari hasil analisis daya serap pada penguasaan menghitung luas permukaan bangun ruang sisi datar dan sisi lengkung di Kabupaten Lampung Tengah hanya sebesar 23,23\%, pada tingkat propinsi sebesar 33,40\%, dan pada tingkat nasional hanya sebesar 38,93\%. Hal ini menunjukkan bahwa penguasaan konsep peserta didik pada materi bangun ruang masih kurang memuaskan.

Rendahnya prestasi belajar matematika peserta didik kemungkinan tidak hanya disebabkan oleh pembelajaran yang masih monoton, akan tetapi perbedaan karakteristik peserta didik juga ikut mempengaruhi prestasinya, antara lain sikap kreatif yang dimiliki peserta didik.

Sikap kreatif merupakan kecenderungan berperilaku yang menghasilkan daya cipta atau gagasan baru dalam menghadapi suatu masalah. 
Ada peserta didik yang memiliki sikap kreatif yang tinggi sehingga dalam mempelajari konsep matematika mampu menghasilkan ide atau gagasan baru dan tidak mudah menyerah dalam memecahkan suatu permasalahan. Namun, ada juga peserta didik yang sikap kreatifnya rendah sehingga kurang optimal dalam belajar matematika.

Anderson (1980) dalam Suharnan (2011: 140) menyatakan bahwa "jika melihat orang-orang yang memiliki kreativitas luar biasa, maka di dalam diri mereka dapat ditemukan sikap kreatif yang menjadi kepribadiannya". Menurut Alex Sobur (2003: 361), sikap adalah kecenderungan bertindak, berpikir, berpersepsi, dan merasa dalam menghadapi objek, ide, atau gagasan. Sedangkan kreatif berarti memiliki daya cipta, kemampuan untuk menciptakan, bersifat mengandung daya cipta.

Suharnan (2011:

menyatakan bahwa sikap merupakan kondisi awal yang penting bagi suatu perbuatan, karena ada kecenderungan yang kuat pada diri seseorang untuk memberikan perhatian dan melakukan tindakan sesuai dengan keinginannya.

Beetlestone

(2011:2-3)

menyatakan bahwa kreatif berarti melibatkan pengungkapan gagasan dan perasaan serta penggunaan berbagai macam cara untuk menemukan, mengeksplorasi, dan mencari kepastian untuk menyelesaikan suatu permasalahan. Seseorang yang kreatif melihat sesuatu yang sama tetapi melalui cara berpikir berbeda. Lebih lanjut Utami Munandar (2009: 45) mengungkapkan bahwa setiap individu pada dasarnya memiliki bakat kreatif dan kemampuan untuk mengungkapkan dan mengembangkan dirinya secara kreatif meskipun dalam ukuran yang berbeda-beda pada masing-masing individu. Hidup kreatif berarti mengembangkan kemampuan yang dimilikinya secara optimal dan mencoba gagasan atau hal-hal baru.

Sejalan dengan pendapat tersebut, Fitriyan Dennis (2009: 12) menyatakan bahwa semakin kreatif seseorang semakin banyak alternatif pemecahan masalah yang ditemukannya. Selanjutnya menurut Suharnan (2011: 139-140), "sikap kreatif melihat aspekaspek yang positif dari setiap persoalan atau gagasan dan melihat bagaimana prospek di depan". Sikap kreatif dibangun atas dasar kecenderungan untuk terus maju dan melihat ke depan, kesanggupan membangun, dan kecintaan seseorang terhadap sesuatu yang baru.

Sejalan dengan pendapat di atas, Monty dan Fidales (2003: 110) mengungkapkan bahwa ciri-ciri sikap kreatif terdiri atas:

a. memiliki rasa ingin tahu yang mendorong seseorang lebih banyak mengajukan pertanyaan, peka dalam pengamatan, dan selalu ingin mengetahui dan meneliti,

b. memiliki imajinasi yang tinggi, yakni kemampuan memperagakan 
dan membayangkan hal-hal belum pernah terjadi,

c. merasa tertantang oleh kemajuan yang mendorongnya untuk mengatasi masalah yang sulit,

d. berani mengambil resiko yang membuat orang kreatif tidak takut gagal.

Menurut Utami Munandar (2009: 70), sikap kreatif dioperasionalkan dalam dimensi sebagai berikut.

1. Keterbukaan terhadap pengalaman baru.

2. Kelenturan dalam berpikir.

3. Kebebasan dalam ungkapan diri.

4. Menghargai fantasi.

5. Minat terhadap kegiatan kreatif.

6. Kepercayaan terhadap gagasan sendiri.

7. Kemandirian dalam memberi pertimbangan.

Kemampuan memecahkan masalah merupakan hal yang penting bagi peserta didik termasuk pemecahan masalah matematika. Melalui kegiatan pemecahan masalah peserta didik mampu mengembangkan kreativitas belajar yang dimilikinya. Perbedaan sikap kreatif yang dimiliki peserta didik menyebabkan perbedaan dalam memecahkan suatu masalah. Setiap peserta didik memiliki cara tersendiri dalam menentukan pemecahan masalah.

Dari uraian di atas, penelitian ini bertujuan untuk mengetahui manakah yang mempunyai prestasi belajar matematika yang lebih baik, peserta didik yang memiliki sikap kreatif tinggi, sedang, atau rendah

\section{METODE PENELITIAN}

Pengambilan sampel dalam penelitian ini dilakukan dengan cara stratified cluster random sampling sebanyak 271 peserta didik.

Metode yang digunakan untuk mengumpulkan data adalah dokumentasi dan metode angket. Uji coba instrumen angket meliputi uji validitas isi, reliabilitas, dan indeks konsistensi internal. Uji hipotesis menggunakan anava satu jalan dengan sel tak sama.

\section{HASIL PENELITIAN}

Hasil perhitungan uji hipotesis dengan analisis variansi satu jalan dengan sel tak sama disajikan pada Tabel 1

Tabel 1. Perhitungan analisis variansi satu jalan dengan sel tak sama

\begin{tabular}{|c|c|c|c|c|c|}
\hline $\begin{array}{c}\text { Sumb } \\
\text { er }\end{array}$ & JK & dk & RK & & \\
\hline Sikap & $\begin{array}{c}15256,5 \\
4761995 \\
\text { Galat }\end{array}$ & $\begin{array}{c}2 \\
268\end{array}$ & $\begin{array}{c}7628,2 \\
73 \\
231,32 \\
7\end{array}$ & $\begin{array}{c}32,97 \\
6\end{array}$ & 3 \\
\hline Total & $\begin{array}{c}77252,2 \\
14\end{array}$ & 270 & & & \\
\hline
\end{tabular}

Dari Tabel 1 diperoleh hasil bahwa $F_{\text {obs }}$ pada sikap kreatif lebih dari $F_{\alpha}$. Hal ini berarti keputusan uji untuk $\mathrm{H}_{0}$ ditolak, sehingga diperoleh kesimpulan bahwa 
sikap kreatif peserta didik berpengaruh terhadap prestasi belajar matematika peserta didik. Oleh karena sikap kreatif mempunyai tiga kategori maka perlu dilakukan uji komparasi ganda. Hasil uji komparasi ganda dapat dilihat pada Tabel 2.

Tabel 2. Perhitungan komparasi ganda

\begin{tabular}{|l|l|c|l|}
\hline $\mathrm{H}_{0}$ & $\mathrm{~F}_{\text {obs }}$ & $2 . \mathrm{F}_{0,05 ; 2,262}$ & $\begin{array}{c}\text { Keputusan } \\
\text { Uji }\end{array}$ \\
\hline & 25,350 & 6 & $\mathrm{H}_{0}$ ditolak \\
\hline & 65,806 & 6 & $\mathrm{H}_{0}$ ditolak \\
\hline & 13,648 & 6 & $\mathrm{H}_{0}$ ditolak \\
\hline
\end{tabular}

Berdasarkan hasil perhitungan uji komparasi ganda, dengan untuk masing-masing hipotesis diperoleh hasil bahwa $F_{\text {obs }}$ Dengan demikian, keputusan ujinya adalah $\mathrm{H}_{0}$ ditolak. Hal ini berarti bahwa rerata yang diperoleh dari masing-masing sikap kreatif berbeda secara signifikan sehingga diperoleh kesimpulan sebagai berikut.

1) Rerata yang diperoleh dari sikap kreatif tinggi berbeda secara signifikan dengan rerata yang diperoleh dari sikap kreatif sedang.

2) Rerata yang diperoleh dari sikap kreatif tinggi berbeda secara signifikan dengan rerata yang diperoleh dari sikap kreatif rendah.

3) Rerata yang diperoleh dari sikap kreatif sedang berbeda secara signifikan dengan rerata yang diperoleh dari sikap kreatif rendah.

\section{PEMBAHASAN}

Setelah dilakukan uji komparasi ganda diperoleh hasil bahwa rerata yang diperoleh dari sikap kreatif tinggi berbeda secara signifikan dengan rerata yang diperoleh dari sikap kreatif sedang maupun rendah. Jika dilihat dari rerata marginalnya, rerata yang diperoleh dari sikap kreatif tinggi lebih tinggi dibandingkan rerata yang diperoleh dari sikap kreatif sedang maupun rendah maka diperoleh kesimpulan bahwa prestasi belajar matematika peserta didik yang memiliki sikap kreatif tinggi lebih baik dibandingkan prestasi belajar matematika peserta didik yang memiliki sikap kreatif sedang maupun rendah.

Berdasarkan uji komparasi ganda diperoleh hasil bahwa rerata yang diperoleh dari sikap kreatif sedang berbeda secara signifikan dengan rerata yang diperoleh dari sikap kreatif rendah. Jika dilihat dari rerata marginalnya, rerata dari peserta didik yang memiliki sikap kreatif sedang lebih tinggi dibandingkan dengan rerata peserta didik yang memiliki sikap kreatif rendah, maka diperoleh kesimpulan bahwa prestasi belajar matematika peserta didik yang memiliki sikap kreatif sedang lebih baik dibandingkan prestasi belajar matematika peserta didik yang memiliki sikap kreatif rendah. Hasil ini sesuai dengan hipotesis penelitian yang menyatakan bahwa prestasi belajar matematika peserta didik yang memiliki sikap kreatif tinggi lebih baik dibandingkan peserta didik yang 
memiliki sikap kreatif sedang maupun rendah dan peserta didik yang memiliki sikap kreatif sedang lebih baik dibandingkan peserta didik yang memiliki sikap kreatif rendah. Hal ini dikarenakan pada peserta didik yang sikap kreatifnya tinggi memiliki keingintahuan yang tinggi dan terus berusaha pantang menyerah dalam mencari pemecahan masalah. Selain itu, peserta didik yang memiliki sikap kreatif tinggi mempunyai kepercayaan diri yang tinggi dalam mengungkapkan gagasan atau ide dalam memecahkan solusi.

Hal ini sejalan dengan penelitian yang dilakukan oleh Harmono (2009) yang menyimpulkan bahwa terdapat perbedaan prestasi belajar antara peserta didik yang memiliki kreativitas tinggi, sedang, dan rendah.

\section{KESIMPULAN DAN SARAN}

Berdasarkan hasil penelitian dan pembahasan, disimpulkan bahwa prestasi belajar matematika peserta didik yang memiliki sikap kreatif tinggi lebih baik dibandingkan peserta didik yang memiliki sikap kreatif sedang maupun rendah dan prestasi belajar matematika peserta didik yang memiliki sikap kreatif sedang lebih baik dibandingkan peserta didik yang memiliki sikap kreatif rendah.

Dari simpulan di atas, maka dapat disarankan sebagai berikut.
1. Berdasarkan penelitian yang telah dilakukan bahwa prestasi belajar matematika peserta didik yang memiliki sikap kreatif tinggi lebih baik dibandingkan yang rendah, disarankan guru dapat mengembangkan sikap kreatif yang dimiliki peserta didik melalui pembelajaran matematika yang aktif dan kreatif sehingga berdampak pada prestasi belajar yang optimal.

2. Bagi peserta didik, hendaknya terus mengembangkan sikap kreatif yang dimilikinya dengan cara mencoba mengerjakan soalsoal yang bervariasi dan tidak mudah menyerah dalam memecahkan permasalahan yang dihadapi khususnya dalam pembelajaran matematika.

\section{DAFTAR PUSTAKA}

Pusat Penilaian Pendidikan. 2011. Laporan Hasil Ujian Nasional SMP/MTs 2010-2011. Jakarta: Balitbang Kemendikbud.

Alex Sobur. 2003. Psikologi Umum. Bandung: Pustaka Setia.

Beetleston, F. 2011. Creative Learning. Bandung: Nusa Media.

Fitriyan Dennis. 2009. Berpikir Kreatif. Jakarta: Esensi.

Harmono. 2009. Eksperimentasi Pembelajaran Kooperatif Tipe 
ISSN 2442-5419 Vol. 3, No. 2 (2014) 10-15

STAD dan Tipe STAD yang Dimodifikasi pada Materi Logika Matematika Terhadap Hasil Prestasi Belajar Matematika Ditinjau dari Kreativitas Belajar Siswa Madrasah Aliyah di Kabupaten Ngawi. Tesis. Surakarta: Universitas Sebelas Maret.

Monty P. Satiadarma dan Fidalis E. Waruwu. 2003. Mendidik Kecerdasan. Jakarta: Media Grafika.

Suharnan. 2011. Kreativitas Teori dan Pengembangan. Surabaya: Laros.

Utami Munandar. 2009. Pengembangan Kreativitas Anak Berbakat. Jakarta: Rineka Cipta. 